\title{
Cervical Papillary Squamous Cell Carcinoma
}

National Cancer Institute

\section{Source}

National Cancer Institute. Cervical Papillary Squamous Cell Carcinoma. NCI Thesaurus. Code C40192.

A human papillomavirus-related cervical squamous cell carcinoma characterized by the presence of papillary structures covered with epithelial cells which show features of cervical intraepithelial neoplasia. The malignant cellular component below the papillary structures is a squamous cell carcinoma. 